\title{
Impact of Agro Technology on Socio-economic Condition of the Farming Groups at Jagannathpur
}

\section{Sushan Chowhan}

Adaptive Research and Extension Division, Bangladesh Institute of Nuclear Agriculture, Sub-station, Ishurdi, Pabna, Bangladesh

"Corresponding author: sushan04@yahoo.com (ORCID ID: 0000-0001-6168-2402)

Paper No. 886

Received: $12-02-2021$

Revised: 22-02-2021

Accepted: 13-03-2021

\begin{abstract}
Agriculture is being highly technologized today; to sustain production and gain higher yields, farmers have to be updated regarding available technologies. As the land area is decreasing, there's always a challenge to increase production and earn profit. Therefore, technological innovations also change farmers' socio-economic conditions. Considering this, an interview on three categories (landless, marginal, small) of 15 farmers was conducted at the Jagannathpur union of Kumarkhali upazilla under the Kushtia district to investigate the socio-economic status, problems in crop production, potentials, limitations of rural development and adoption extent of modern agricultural technologies. Outcomes expressed that, a major source of annual income $(1,20,800 \mathrm{Tk})$ of landless farmers were from non-agricultural works; contrary, marginal (2,89,000 Tk) and small (3,89,200 Tk) farmers' prime source of income was from agricultural origins. It was a positive sign that all categories of farm families spent a good sum of money for educating children immediately after food expenditure. All the farmers had drinking water, electricity and hygienic toilet facilities at their dwelling house. The problem confrontation index (PCI) of rural development was highest in lack of capital (36). Physical and social PCI was identified as limited natural resources (32) and reduction of croplands (28), respectively. Concerning technology adoption, $14 \%$ used biofertilizer, $12 \%$ followed a modern model of vegetable production, $12 \%$ collected quality seeds, $10 \%$ exercised mulching, $10 \%$ used perching and $10 \%$ imitated seed preservation techniques. Top PCI for crop production was high input cost (36) followed by lack of technical knowledge (34). Most of the respondents agreed that agricultural production directly contributes to food security (34), increased nutrition (32) and financial safety (30).

\section{Highlights}

( Rural farmers are getting involved in alternative agricultural income sources besides farming.

( Efficient extension and communication strategies are playing a vital role in technology transmission and rural development.
\end{abstract}

Keywords: Homestead vegetable production, rural development, Kumarkhali, socio-economic condition, income generating activities (IGA), problem confrontation index (PCI)

Bangladesh is an agrarian country whose agriculture is rural Area based (Hasan et al. 2015). Farming is the ancient and most common profession here. Over $50 \%$ of country's total population lives in rural Area and their main source of income is agriculture based. Thus, most of the villagers (47\% manpower in agriculture) are engaged in farming. One of the key causes of having usual affinity to farming is: the soil is highly prolific and huge Area of the country is plane. The second fascinating matter is, countrymen are naturally good at farming. Agricultural sector is the individual greatest contributor to GDP (Gross Domestic Product). The crop sub-sector governs the agriculture sector supplying approximately

How to cite this article: Chowhan, S. 2021. Impact of Agro Technology on Socio-economic Condition of the Farming Groups at Jagannathpur. IJAEB, 14(1): 97-109.

Source of Support: NATP-2 BARC; Conflict of Interest: None (c) 
$72 \%$ of the entire production. Fisheries, forestry and livestock sub-sectors contributes $10.33 \%, 7.33 \%$ and $0.11 \%$ respectively (BBS 2019). Amongst the economic sectors of Bangladesh; the agricultural economy plays a vital role that directly influences the development of the national economy. The current contribution of the agriculture sector to the GDP, is about $12.68 \%$ (Databd.Co, 2019). Bearing a population nearing 163 million, it is the $8^{\text {th }}$ most populous country in the world and has a population density of $1,115.62$ people $/ \mathrm{km}^{2}$ (World Population Review, 2019). Though lands are fertile, due to drought, salinity and unsuitable lands, crop cultivation is limited to more or less $70 \%$ of the total Area of the country, which is decreasing at a rate of about $1 \%$ annually (Hossain et al. 2015). Currently, the national average cropping intensity is almost $2 \%$ (FAO 2016). Scopes for horizontal extension of arable land is quite tough, but cropping intensity can be reached to $400 \%$. This may be gained through adopting a series of modern agro-technologies such as new modern high yielding short duration and stress-tolerant varieties of cereal, pulse, oilseed, vegetable, fiber, etc. crops (Chowhan et al. 2020).

Recently with the development of early maturing varieties of the above crops, space been created to accommodate four crops in the same piece of land in a year (BARI 2019). Contrary, the yield gap has to be reduced by eradication of monocropping to get the desired productivity of a crop (Islam et al. 2018). As a result, agronomists are in the challenge of developing improved crop production technologies, address production problems, processes and management of problems to maximize the production efficiency of an individual crop with optimum management practices (Hossain et al. 2015). Almost all the household in the village have homestead vegetable garden; which is a useful source of year-round nutrition supply to the family and also for income-generating activities. Vegetables are highly profitable on the basis of their returns to investment (Mohiuddin et al. 2009). Vegetables are cultivated in only $1.8 \%$ of the total cultivatable land in Bangladesh (BBS, 2018). Only 3.48\% of total land covering $4,97,640$ hectares belonged to vegetables and over $70 \%$ of the land is covered by rice cultivation (BBS 2018; Chowhan et al. 2019). To increase the cultivation of vegetables and extend the yield of all crops, it's necessary to include farmers' in production, planning, training and ascertain problem-solving related to agricultural production.

Rural farmers already adopted proven modern technologies as a strategy for profit and more income from their farm production. New innovations and agricultural technologies have greatly influenced their mode of life leading style as well as livelihood. They are doing continuous testing(s) on how they can produce maximum yield with minimum input (labor, fertilizer, irrigation, pesticide, etc.). Thus, new agricultural technologies are positively affecting their socio-economic conditions and, as a whole, contributing to cumulative rural development. Though, Bangladesh already ranked $3^{\text {rd }}$ in terms of global vegetable and rice production (Chowhan, 2020); but there's still some problem which needs to be addressed. Considering this situation, the present investigation were undertaken to fulfill the following objectives-

- To know the socio-economic status of different categories of farmers.

- To find out the major challenges and problems faced during crop production.

- To determine the extent of problem confrontation of the farmers in vegetable cultivation.

- To Identify potentials and limitations of rural development issues.

- To know the status of adoption of different agriculture technologies.

\section{METHODOLOGY}

\section{Location of the study}

The locale of the study was Jagannathpur union (Fig. 1) of Kumarkhali upazilla under Kushtia district of Khulna division (GPS position was $23^{\circ} 52^{\prime} 42.8^{\prime \prime} \mathrm{N}$ latitude and $89^{\circ} 16^{\prime} 17.5^{\prime \prime} \mathrm{E}$ longitude). Agro-Ecological Zone (AEZ) of the site was 11; which is high Ganges river flood plain and mostly high to medium high land type characterized by lower content of organic matter and fertility level (Ahmed et al. 2018). 


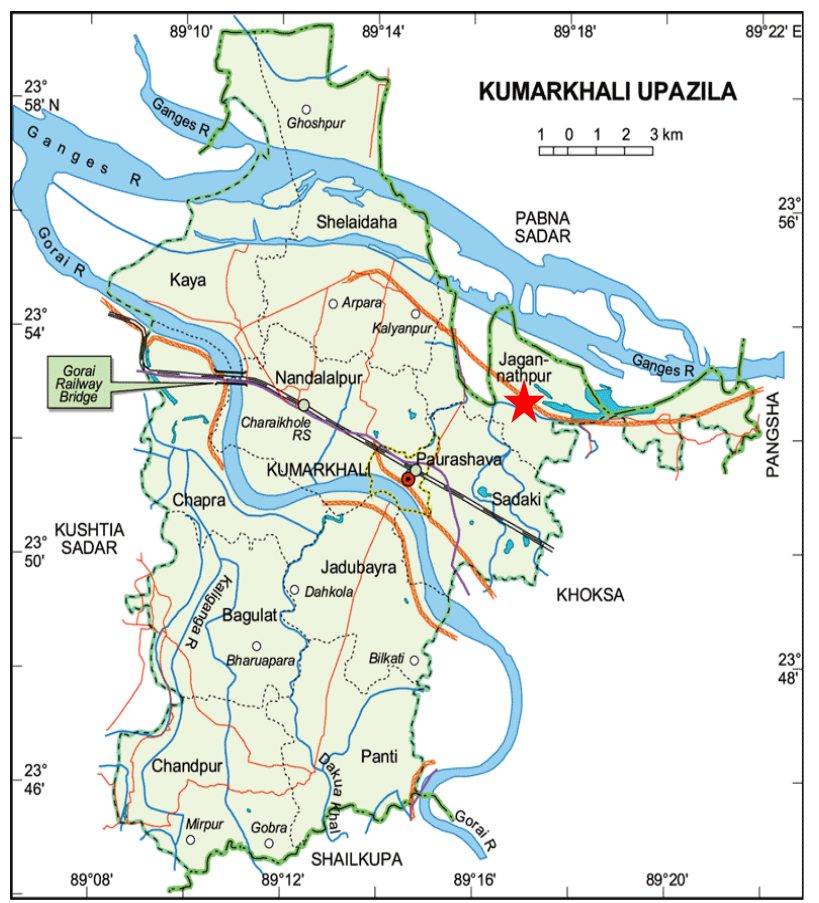

Fig. 1: Map showing the study area of Kumakhali upazilla (Star marked)

\section{Sample}

Fifteen farmers were selected randomly from the target area from three different categories of farm sizes; each category consisted of five farmers. The farm categories were-

- A landless farmer having farm size of 0.02 to $<0.2$ ha.

- Marginal farmer having farm size of 0.2 to < 0.6 ha.

- Small farmer having farm size of 0.6 to $<1$ ha.

Farm size was measured for each respondent in terms of hectares by using the following formula:

$$
\text { Farm size }=a+b+0.5(c+d+e+f)
$$

Where, $a=$ homestead area including pond; $b=$ Own land under own cultivation; $c=$ Area shared in borga by the respondents; $d=$ Area shared out borga by the respondents; $e=$ Area leased in by the respondents; $f=$ Area leased in by the respondents

\section{Selection of variable}

Success of research depends on the successful selection of variables. Variable were selected by reviewing relevant literature and discussing with relevant experts. The selected characteristics of the farmers were: age, education, family size, farm size, house hold's physical condition, loan status, annual family income, expenditure, cosmopoliteness, extension contact, knowledge on vegetables cultivation. These characteristics of the vegetable growers constituted the independent variable of the study. Production of homestead vegetables, income generation through vegetable and enhanced food security was the main focus of the study, which constituted the only dependent variable of the study. Other variables like, membership in different social institutions, role of family members in decision making, technologies already adopted and interested to adopt, agriculture input source, services, specific areas for homestead cultivation, linkage with extension, training received and perception of crop production problems and socioeconomic conditions from an individual point of view was also taken into account.

\section{Instrument for collection of data}

With the view to collect relevant information, an interview schedule was prepared with the help of the module director and related experts, carefully keeping the objectives of the study in mind. The interview schedule contained both opened and closed form of questions to obtain information regarding the homestead vegetable cultivation of the respondents.

\section{Measurement of variables}

In order to conduct the study in accordance with the objectives, it was necessary to measure the selected variables. This section contains procedures for the measurement of both dependent and independent variables of the study. The procedures followed for measuring the variables are presented below:

\section{Measurement of independent variables}

The procedures for measuring the independent variables are described below:

Age

The age of a respondent was measured in terms of actual years from his birth to the time of interview. A score of one (1) was assigned for each year of age. No fraction of the year was considered. 


\section{Education}

Education was measured in terms of grades of education completed by an individual from any formal education institution. It was expressed in terms of year of schooling. A score of one (1) was assigned for each year of successful schooling completed. If a respondent did not know how to read and write, his education score was given as '0' (zero). A score of 1 (one) was given to that respondent who could sign his name only; if a score of ' 2 ' was given, the respondent studied between class 6 to 10 (SSC). Those were between HSC to Honors ' 4 ' was given.

\section{Family size}

Family size of a respondent was determined in terms of the total number of family members of that respondent. The family members included the respondent himself, his wife, sons, daughters, brothers, sisters, parents and any other person who jointly live and eat together at the time of interview. The scoring was done by the actual number mentioned by the respondent.

\section{Annual family income}

The annual family income of a respondent was measured on the basis of total yearly earning from agriculture, non-agriculture and other sources (service, business, daily labor etc.) by the respondent himself and other family members of the respondent. The annual family income of a respondent was expressed in '000' taka.

\section{Cosmopoliteness}

The Cosmopoliteness of a respondent was measured in terms of his nature of a visit to the four different external places to his own social system. A scale was developed arranging the score of $0,1,2$ and 3 to the responses for never, rarely, occasionally and frequently visit these places respectively. The cosmopoliteness score of the respondents could range from 0 to 18 , while 0 indicating no cosmopolites and 18 indicating very high cosmopolites.

\section{Problems faced by farmers}

It may be mentioned here that farmers might face a wide variety of problems in respect of vegetable cultivation. Each farmer was asked to indicate the extent of difficulty caused by each of the problems by checking any of the four responses such as "greatly", "moderately", "partially" and "not at all" and score were assigned to these responses as 3, 2, 1 and 0 respectively. Problem confrontation in vegetable cultivation score for each farmer was computed by adding his scores for all the 11 problems. Thus, the problem confrontation score of a respondent could range from 0 to 33 while 0 indicating no problem confronting and 33 indicating very high problem confronting in vegetable cultivation. Measurement of Problem Confrontation Index (PCI) to compare the severity of the problems is stated below.

A Problem Confrontation Index (PCI) was computed for each of 11 selected problems by using the following formula:

Problem Confrontation Index $(\mathrm{PCI})=$

$$
\left(P_{g} \times 3\right)+\left(P_{m} \times 2\right)+\left(P_{p} \times 1\right)+\left(P_{n} \times 0\right)
$$

Where,

$P_{g}=$ Total number of respondents indicating great problem confrontation; $P_{m}=$ Total number of respondents indicating moderate problem confrontation; $P_{p}=$ Total number of respondents indicating partial problem confrontation; $P_{n}=$ Total number of respondents indicating no problem confrontation.

Problem Confrontation Index (PCI) for each of the selected problems could range from 0 to 45 , where 0 indicated no problem confronting and 45 $(15$ respondents $\times 3$ ) indicated the highest problem confrontation.

\section{Data collection procedures}

At first, a sitting was done with Upazilla Agriculture Officer and other officials (Sub Assistant Agriculture Officer-SAAO) of Kumarkhali upazilla for collection of secondary data to understand socio-economic condition and livelihood pattern of farmers. Then data were collected by interviewing the sample of 15 farmers from Jagannathpur union of Kumarkhali upazilla with the help of an interview schedule. Data were collected with cooperation with the SAAO of the respective study area. The respective SAAO of the study area introduced local leaders 
who were very helpful for the collection of data. Rapport was established with the farmers prior to an interview and the objectives of the study were clearly explained by using local language as per as possible. As a result, the respondents did not hesitate to furnish proper responses to the questions and statements. Data were collected during the period from 05 -11 February 2021. No serious problem was confronted by the researcher in collecting data.

\section{Data processing and Analysis}

After completion of the field survey, data from all the interview schedules were coded, compiled, tabulated and analyzed in accordance with the objectives of the study. In this process, all the responses in the interview schedules were given numerical coded values. Local units were converted into standard units. Qualitative data were converted to quantitative ones by means of suitable scoring whenever necessary. The responses to the questions in the interview schedules were transferred to a master sheet to facilitate tabulation. The statistical measures used in describing the selected dependent and independent variables were number and percent distribution, range, mean, standard deviation and coefficient of variation by using the statistical program Statistics 10 (Statistix 2021).

\section{RESULTS AND DISCUSSION}

Findings and logical interpretation of the results have been presented and described according to the objectives of the study in this chapter.

\section{Selected Characteristics of the Respondents}

Eight selected characteristics of the vegetable farmers were considered as the independent variables of the present study. Descriptive statistics regarding these eight characteristics have been presented in Table 1. Category-wise number of the respondent have been presented in Table 2 according to their eight selected characteristics. The age of the respondents ranged from 20 years to 65 years and the mean age was 41.867 years. This implies that most of the rural farmers were middle-aged and above. The youngers were mostly less interested in agriculture-related works and they were most interested in fixed-salary jobs because in agro-based works, risks are high. As the farmers are middle-aged, thus the variation (3 years to 40 years) in experience was larger. The mean skill period was 22.33 years. Typical family members of the surveyed respondents were 5.60 and their maximum and minimum numbers were 10 and 3, respectively. Education score was observed highest 20 and lowest 4; indicating that lower education illiteracy and more upper the score more the level of educated farmers and their family. Mean score of 8.80 points elicited that the level of education is moderate.

In this study, three levels of farmers were taken into consideration (landless, marginal, small). So, their farm size was pre-defined. Median farm size was noticed to be 0.4893 ha and the maximum and minimum value was 0.06 ha and 0.87 ha. The mean net annual family income was 3,46,840 BDT among the evaluated farmers. A large disparity $(4,22,000 \mathrm{BDT})$ in maximum and minimum income was noticed. This might be due to the farmers' category and limited source of IGAs (incomegenerating activities). The lending behavior of the respondents was seen quite higher. The mean loan per farmer was 60,067 BDT. Mostly loans were taken for business, medical, house building, agricultural investment and for occasional (marriage) purposes. Approximately $50 \%$ of the farmers took a loan from

Table 1: Descriptive statistics of farmers characteristics ( $\mathrm{n}=15)$

\begin{tabular}{|c|c|c|c|c|c|c|c|}
\hline \multirow{2}{*}{ S1. No. } & \multirow{2}{*}{ Characteristics } & \multirow{2}{*}{ Measuring unit } & \multicolumn{2}{|c|}{ Range } & \multirow{2}{*}{-Mean } & \multirow{2}{*}{$\begin{array}{l}\text { Standard } \\
\text { deviation }\end{array}$} & \multirow{2}{*}{$\mathrm{CV} \%$} \\
\hline & & & Possible & Observed & & & \\
\hline 1 & Age & Years & - & $20-65$ & 41.867 & 13.861 & 33.107 \\
\hline 2 & Agricultural experience & Years & - & $3-40$ & 22.333 & 13.146 & 58.861 \\
\hline 3 & Family size & Numbers & - & 3-10 & 5.60 & 1.805 & 32.228 \\
\hline 4 & Education & Score (Schooling year) & $0-30$ & $4-20$ & 8.800 & 4.601 & 52.287 \\
\hline 5 & Farm size & Hectare (ha) & $0.02-0.99$ & $0.06-0.87$ & 0.4893 & 0.2989 & 61.081 \\
\hline 6 & Net annual family income & Thousand taka & - & $154000-576000$ & 346840 & 128908 & 37.166 \\
\hline 7 & Loan Amount & Thousand taka & - & $0-400000$ & 60067 & 100104 & 166.65 \\
\hline 8 & Cosmopoliteness & Score & $0-18$ & $2-18$ & 5.533 & 2.263 & 40.908 \\
\hline
\end{tabular}


Table 2: Number of farmers availing different social facilities in their dwelling area

\begin{tabular}{|c|c|c|c|c|c|c|c|c|c|c|c|c|}
\hline \multicolumn{2}{|c|}{ Drinking water } & \multicolumn{4}{|c|}{ House Type } & \multicolumn{3}{|c|}{ Electricity source } & \multirow[b]{2}{*}{ Hospital } & \multicolumn{3}{|c|}{ Road type } \\
\hline $\begin{array}{l}\text { Only } \\
\text { HT }\end{array}$ & $\begin{array}{l}\mathrm{HT}+ \\
\text { pond }\end{array}$ & $\begin{array}{l}\text { Semi } \\
\text { concrete }\end{array}$ & Raw & Concrete & $\begin{array}{l}\text { Tin } \\
\text { shaded }\end{array}$ & Toilet & $\begin{array}{l}\text { Only } \\
\text { Grid }\end{array}$ & $\begin{array}{l}\text { Grid+ } \\
\text { Solar }\end{array}$ & & Paved & $\begin{array}{l}\text { Semi } \\
\text { paved }\end{array}$ & Earthen \\
\hline 11 & 04 & 06 & 05 & 03 & 01 & 15 & 15 & 01 & 14 & 11 & 02 & 02 \\
\hline
\end{tabular}

HT- hand tubewell.

Table 3: Usage of modern equipment and access to education, market and religious institutions

\begin{tabular}{lllllllll}
\hline \multicolumn{2}{c}{ Access to educational institutions } & \multicolumn{3}{c}{ Market facility } & \multicolumn{3}{c}{ Religious institutions } & Usage of \\
$\begin{array}{l}\text { Only } \\
\text { primary } \\
\text { school }\end{array}$ & $\begin{array}{l}\text { Primary } \\
\text { school+ } \\
\text { secondary } \\
\text { school }\end{array}$ & $\begin{array}{l}\text { Secondary } \\
\text { school+ } \\
\text { College }\end{array}$ & Market & $\begin{array}{l}\text { Average } \\
\text { Market } \\
\text { distance }\end{array}$ & Mosque & Church & Temple & $\begin{array}{l}\text { modern } \\
\text { equipment }\end{array}$ \\
\hline 05 & 05 & 02 & 15 & $0.83 \mathrm{~km}$ & 15 & 0 & 02 & 15 \\
\hline
\end{tabular}

government banks (Krishi Bank) and others form NGOs. The rate of interest for loan payments was higher in NGOs and less in Krishi Bank. Farmers of Jagannathpur were less cosmopolite, as the average score was 5.533. Thus, they roamed less. The lower mean score may be due to the available essential services in the locality, i.e., in union parishad, upazilla or nearest places.

\section{Dwelling house and social facilities}

Table 2 and 3 denote that all fifteen farmers were found with their own hand-operated tube well and with hygienic toilet facility. They all had electricity in their house, but only one of them had solar electricity service. Six of the respondents had a semiconcrete house, five had a raw house, three had concrete and one had tin shaded dwelling house. Every farmer had access to a nearby hospital except one. The nearest road from the dwelling house of eleven respondents was paved. Of the rest four, two had earthen and two semi-paved roads each. Everyone had an educational, market and mosque facility. No church was found in the locality and just one temple was found. The mean nearer market distance of the participants was $0.83 \mathrm{~km}$; the lowest was $0.2 \mathrm{~km}$ and the highest was $2.5 \mathrm{~km}$. Most of the farmers had access to modern tools machinery and equipment. Landless farmers had TV, freeze and mobile. Marginal farmers had TV, freeze and mobile, shallow machine, mini reaper. The small farmers' group had TV, Freeze, Mobile, laptop, power thresher, power tiller, shallow machine, motorcycle. Actually, differences in machine usage were influenced by farmers' class and economic solvency. Kumar et al. (2020) noticed that adoption of improved technologies and practices significantly increased by improved access to markets, private sector involvement in selling improved seeds, disseminating information and access to credit

\section{Annual Family Income and Expenditure}

A major source of income from non-agricultural parts (Fig. 2) in the landless type farmers were labor source (66,000 Taka) and minimum from other services (12,000 Taka) like doing electric works and also through land leasing. Marginal farmers mostly earned through business and least by providing labor service, machine rental, compost sales. Small farmers had the lowest amount of income from non-agricultural sources (70,320 Taka) among the three groups of farmers. The highest income was generated from foreign remittance (job) $(40,800$ Taka) and the lowest through machine rental and vermicompost sales $(13,920$ Taka).



Fig. 2: Sources of income (Taka) from non-agricultural (Non Agri) activities 
Income from vegetable sales was maximum in the marginal farmers' group (94,000 BDT) and minimum in landless farmers $(58,800 \mathrm{BDT})$. Though marginal and small farmers earned a handsome amount of money from grain crops, but landless farmers didn't have this scope; thus, they only sold vegetables and some livestock products (egg, chicken, milk) only (Fig. 3).

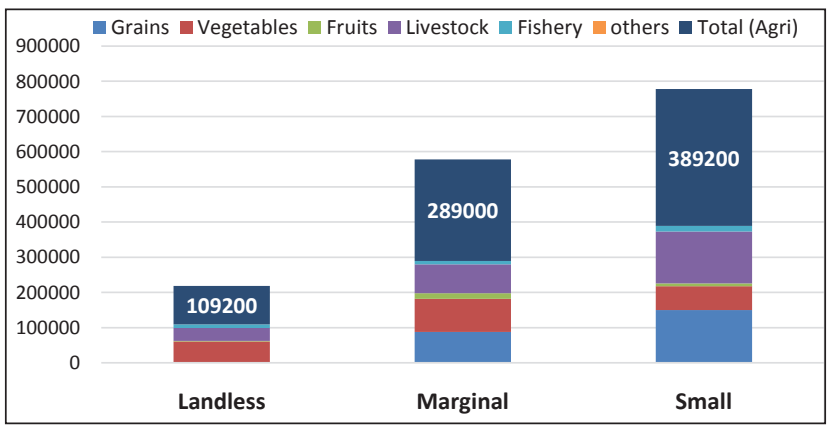

Fig. 3: Sources of income from agricultural (Agri) activities

In terms of expenditure, most is used in food, cloth, education and loan payment (others) (Fig. 4). Landless farmers can effort little amount for house repair and recreation compared to others.

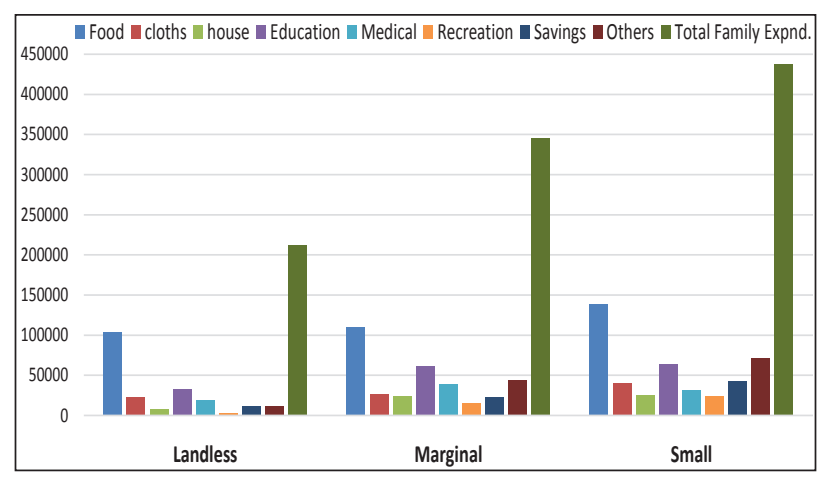

Fig. 4: Area of annual expenditures of three farmers group

Medical expenditure is most in marginal groups and least in landless category. Small farmers have four times more savings (42,500 Taka) than landless (11,750 Taka) and about two times more than marginal farmers (23,000 Taka). Alamgir et al. (2018) reported that the income of farmers varied according to the region and in some regions, agriculture is the main source of income. Salam et al. (2019) concluded that household expenditure was treated as a welfare indicator, which included food and non-food expenditures and among different nonfarm activities, together with agricultural activities ensured significantly higher per capita household expenditure.

\section{Role of family members in decision making}

Regarding decision making on family and other matters participation of male member were dominant $(47.99 \%)$ and females had the role of $40.87 \%$ of the total matters. Children were prioritized to make a decision on the $11.15 \%$ matters (Fig. 5). Children took decisions mostly on food purchase, food cooking, cloth sewing and rarely educational matters. Roy et al. (2017) reported that average annual household income by women was $43.52 \%$ and thereby influenced decision-making process. Tipu (2018) observed variable percentage women participation in different activities like budget making, development function, public relation, education.

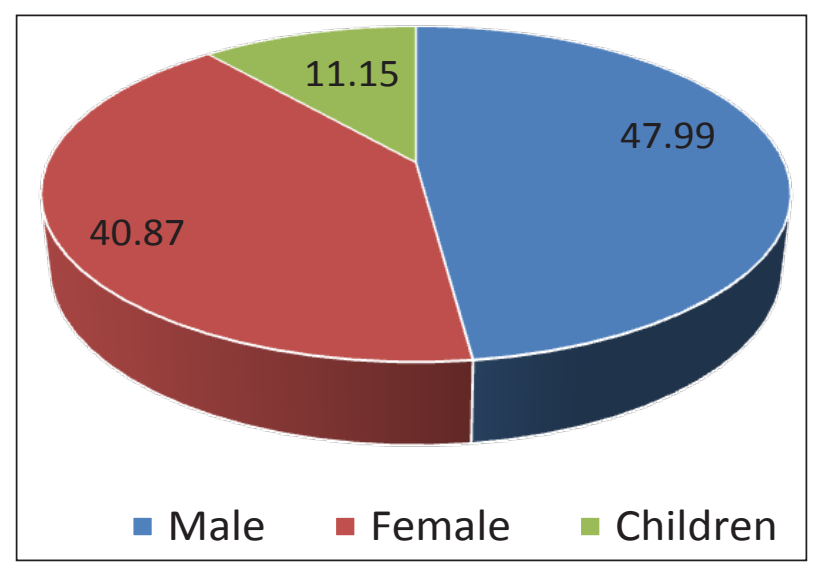

Fig. 5: Gender (\%) participation in decision making.

\section{Problems faced in rural development}

Some limitations of rural development were observed in the study. Thus, a Problem Confrontation Index (PCI) score was computed based on the pre-defined 11 formatted questions and the PCI was calculated (Fig. 6).

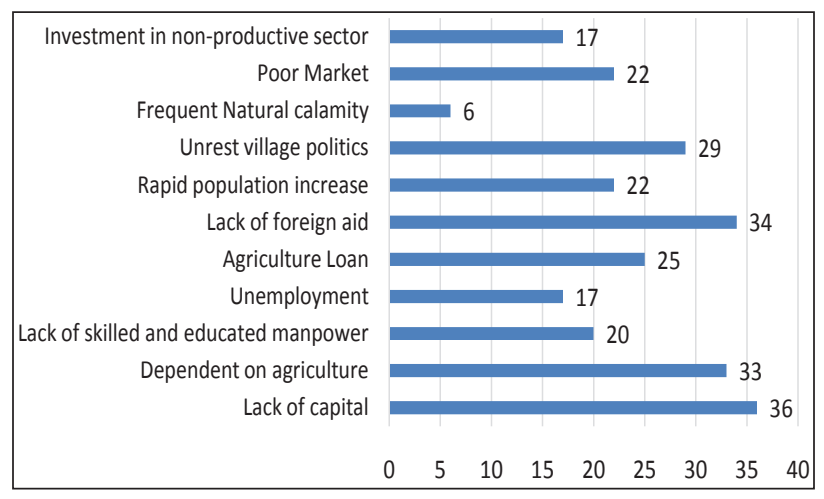

Fig. 6: PCI of defined eleven problems regarding rural development 
It was revealed that lack of capital (36) was the major hindrance, followed by lack of foreign aid (34) and agriculture dependency (33). Frequent natural disasters ranked the last as it had the lowest score (6). Kabir et al. (2019) in a study, uttered that lack of capital was the peak problem in rural women's development.

Limited natural resources ranked first (32) as the prime physical problem for rural development (Fig. 7). Dependent on nature (19) and loss of soil fertility (13) ranked second and third position, respectively. Limited or almost no problem of water sources was observed, resulting lack of water source as the least problem (10) in the PCI.

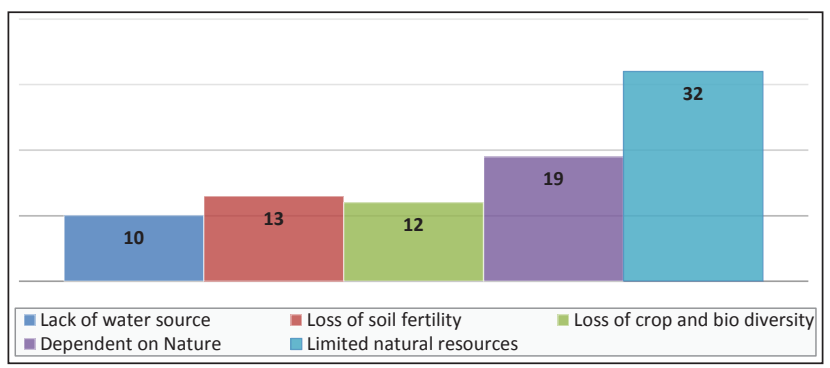

Fig. 7: PCI of selected five physical problems relating to rural development

Seven designated problems were scored based on the PCI and found that (Fig. 8), reduction of cropland ranked top (28) followed by misuse of local government management (27) and influence of special classes for development (26). Illiteracy stood the last position (12) and it had the minimum problem with developmental activities.

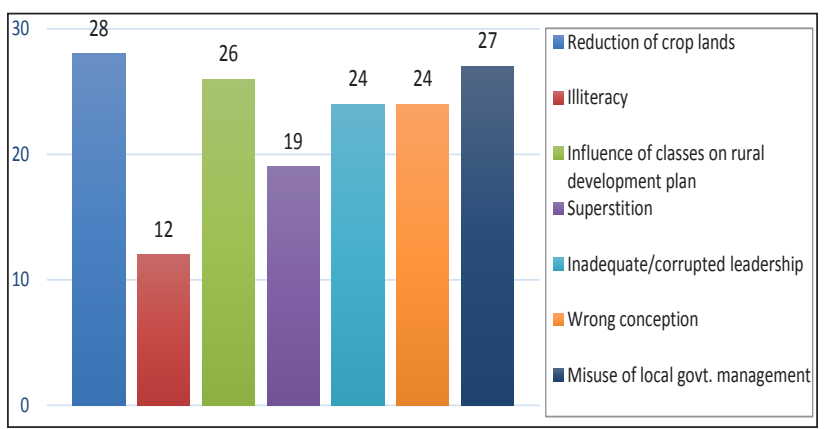

Fig. 8: PCI of chosen seven social problems relating to rural advancement

\section{Area of homestead cultivation}

Different locations inside the homestead were seen to be used for vegetable cultivation by the farmers (Fig. 9). The majority of them utilized homestead boundary $(29.79 \%)$ followed by growing on trellis
$(27.66 \%)$ and on marshy places of the house area $(19.15 \%)$. A minority of the respondents opined that rooftop $(2.13 \%)$ and other places $(2.13 \%)$ were rarely used for cultivation of any crops. As vegetable crops require fencing and protection from herbivores, thus household boundary is used to reduce the cost of cultivation. Contrary, marshy and other places are mostly fallow and there Arum or Taro (Colocasia sp.) type plants are grown. Ferdous et al. (2016) revealed that among three farm groups of 12 households at Rangpur grew year-round vegetables on niches which were an open sunny place, rooftop, trellis, fence, boundary, marshy land and partially shady place.

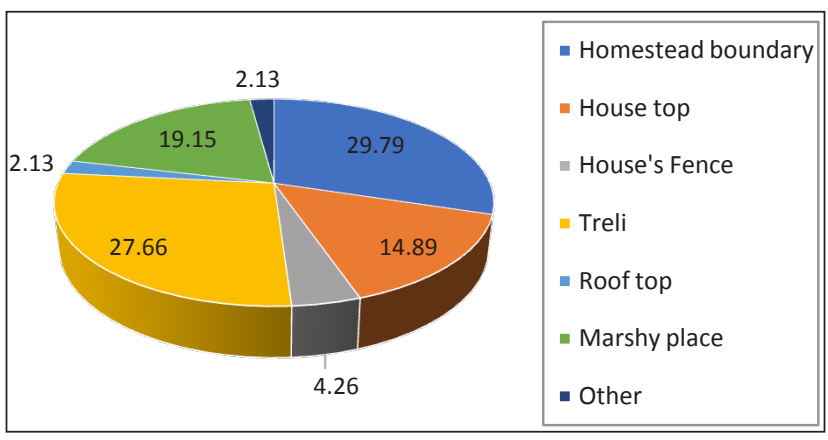

Fig. 9: Area used for homestead crop cultivation

\section{Adopted agricultural technologies}

Modern methods and technologies applied in crop production were assessed (Fig. 10).

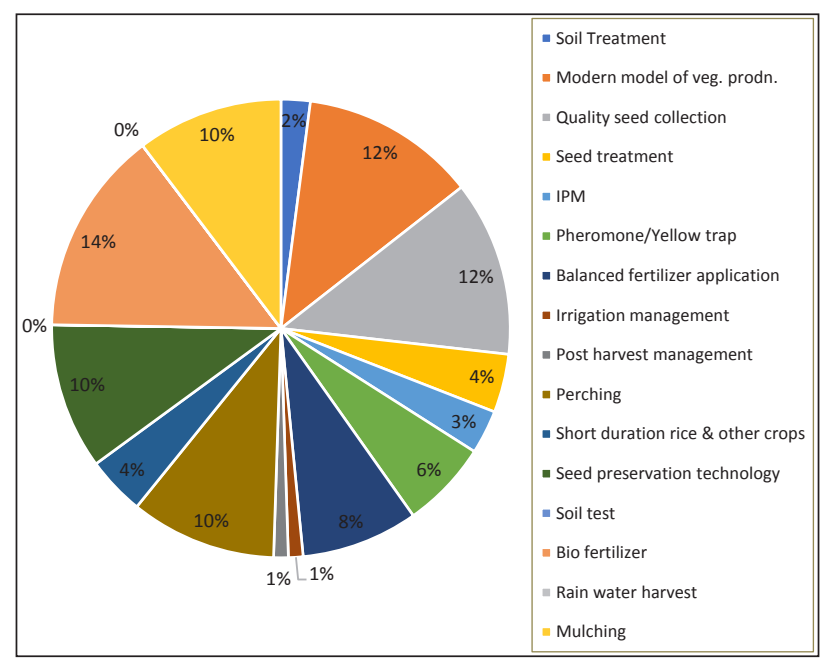

Fig. 10: Adoption of agricultural technologies by the respondents

It was seen that most of them adopted the use of biofertilizer $(14 \%)$ in croplands. $12 \%$ of the farmers were found to be using quality seeds and modern 
models of vegetable production. $10 \%$ of them were in use with perching, seed preservation technologies and mulching. Soil testing and rainwater harvesting were totally absent in their adoption and they never do it. This might be due to the available irrigation source and appropriate soil management through cow dung, sesbania, green manuring, or the growing of leguminous crops. Mottaleb (2018) concluded that the rapid proliferation of useful technologies have profound impacts on rural development. Wossen et al. (2019) stated that adoption of improved agricultural technology could accelerate the diffusion process and thus more emphasis should be given on research and extension.

\section{Communication with extension sources for technology adoption}

Among the eight types of agricultural extension process and technology adoption (Fig. 11), most of the respondents $(27.28 \%)$ were found to contact the extension officers (SAAOs) for problems, technologies and queries related to agriculture. Suggestions, advice, or solution regarding new technologies or any problem (disease, pest, fertilizer) were taken from the input suppliers also which was the second most $(24.07 \%)$ way of communication.

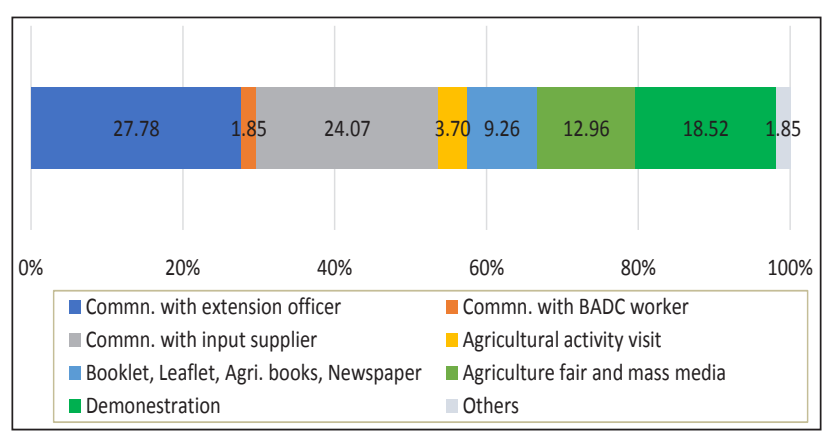

Fig. 11: Media sources used for agricultural technology adoption

Technology adoption from the demonstrations was the third most (18.52\%) effective method to communicate with the farmers, as it created good motivation among the farmers and they believed what they saw in the field. Communication with BADC officer and other media (NGO) was found minimal (1.85\%) in case of any technology adoption. Kumar et al. (2020) narrated that, adoption of improved practices was markedly enhanced through a message from progressive farmers groups, cooperative societies, participation in agricultural fairs, training, farm visits, information from informal sources, cooperatives/farmers organizations, public and private extension organizations.

\section{Perception on the methods of agricultural technology transfer}

PCI of ten methods were ranked as per farmers' perception and views (Fig. 12). Peak score (38) was obtained by 'generating higher income by selecting sustainable technology of farmers' followed by 'field day, technology demonstration, exposure (motivational) visit' (33). 'considering farmers opinions' and 'farmer group building' jointly ranked third (24) which had identical PCI scores. Women participation ranked off-peak and had the lowest PCI score (17). Azumah et al. (2018) carried a study on 543 rice farmers in Ghana and observed, demonstration, farmer-to-farmer and household extension methods were perceived as the most effective agricultural extension methods. Khan and Akram (2012) presented that contact with extension personnel, field days and demonstration were effective means of technology diffusion.

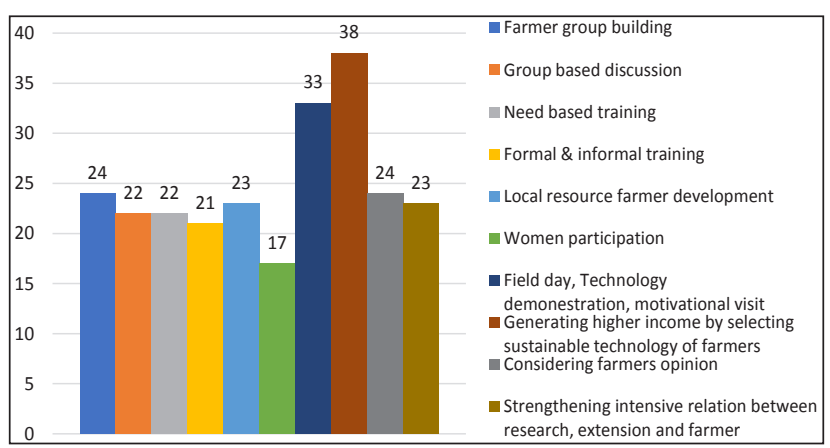

Fig. 12: PCI of farmers view on the methods of agriculture technology dissemination

\section{Problems faced during crop production}

Difficulties faced in crop production were evaluated based on eleven pre-determined problems and a PCI was computed based on the respondents' answers (Fig. 13). 'High input cost' ranked first (36), followed by 'lack of technical knowledge (34). 'lack of capital and 'quality seeds' combinedly ranked third (33). In the case of agriculture works, family members sincerely cooperate; thus 'lack of cooperation by family members stood last position (3) in the PCI. Kabir et al. (2019) also found that lack of quality of seed was one of the prime problems for crop cultivation. Quddus and Kropp (2020) mentioned 
major production constraints as the high cost of labor, equipment rental, pesticides and irrigation.

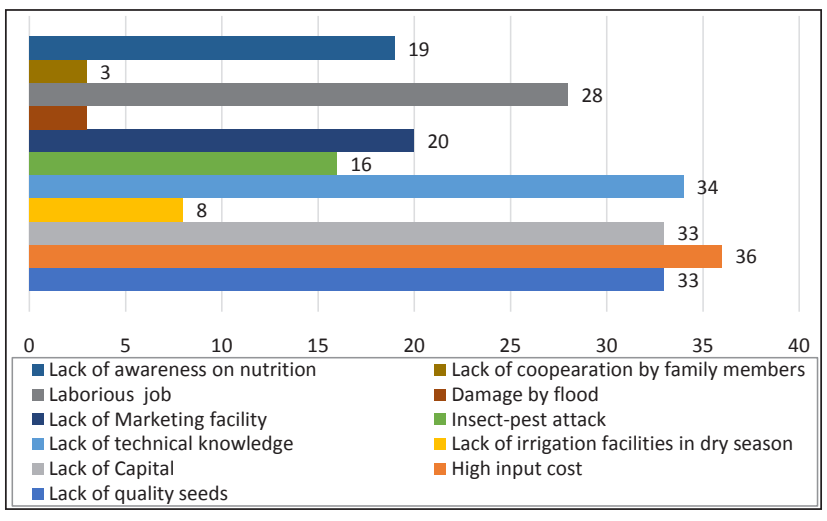

Fig. 13: Crop production related PCI

\section{Socio-economic influence on agricultural production}

Respondents' perception towards role of agricultural production on socio-economic matters and to what extent in influences; a PCI was calculated basing on the response of the farmers on eight definite parameters (Fig. 14).

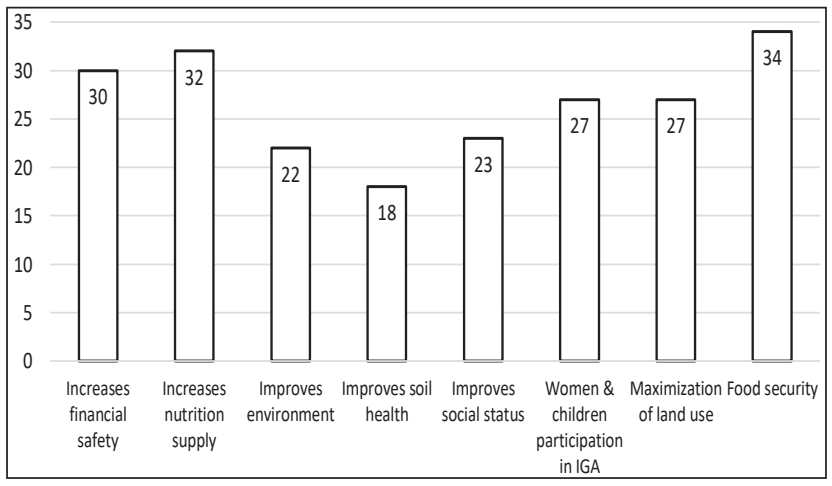

Fig. 14: Effect of socioeconomic conditions on agricultural production

The highest number of farmers (score 34) strongly agreed that it contributes to 'food security. Secondly (score 32) they agreed that it 'improves nutrition supply' and thirdly (score 30) they stated that agriculture 'increased their financial safety. The lowest PCI score (18) was obtained by 'improves soil health' as a minority of the farmers agreed with this statement. Khoza et al. (2019) summarized that, socio-economic factors such as; age, household size, level of education, grain and livestock producers, farm size and access to training influence the participation in agricultural activities.

\section{Training received by the respondents}

Training on crop cultivation, management and other aspects were received by fourteen farmers out of fifteen (Table 4), which were facilitated by the Department of Agricultural Extension (DAE) in the upazilla agriculture training center of Kumarkhali, Kushtia. Through training, farmers gained knowledge, skill and idea about the relevant technology, which motivated them to adopt a given technology.

Table 4: List of agriculture training received by the farmers

\begin{tabular}{lll}
\hline $\begin{array}{l}\text { S1. } \\
\text { No. }\end{array}$ & $\begin{array}{l}\text { No. of } \\
\text { farmers } \\
\text { trained }\end{array}$ \\
\hline 01 & $\begin{array}{l}\text { Modern methods of homestead vegetable } \\
\text { garden establishment and cultivation } \\
\text { techniques }\end{array}$ & 05 \\
02 & $\begin{array}{l}\text { Fruit Garden establishment and cultivation, } \\
\text { Technology of year-round vegetable }\end{array}$ \\
& $\begin{array}{l}\text { production in the homestead, Seed } \\
\text { production of pulse crops, Tuber crops } \\
\text { production technology, Vermicompost } \\
\text { production technology }\end{array}$ \\
03 & $\begin{array}{l}\text { Integrated Pest Management, Irrigation } \\
\text { water management, Modern production } \\
\text { technology of rice }\end{array}$ \\
$04 \begin{array}{l}\text { Cultivation of modern aman rice varieties, } \\
\text { Production technology of spices }\end{array}$ & 01 \\
05 & $\begin{array}{l}\text { Rice, wheat and Jute Seed production, } \\
\text { processing and preservation techniques, }\end{array}$ \\
Fertilizer management of vegetable crops & 01 \\
\hline
\end{tabular}

\section{CONCLUSION}

Jagannathpur union of Kumarkhali is a resourceful upazilla bearing extensive agricultural potentiality of crop, livestock and fishery. Though the average education level of the farmers and their family were moderate almost all of them spent a huge sum of money for the educational purpose of their children. Income-generating activities (IGA) from agriculture and non-agriculture sources were satisfactory in the studied Area. Thus, the average monthly income of eleven farmers was above 20,000 Tk and only four of them were below 20,000 Tk. Though grain crops were the most cultivated but a large number of vegetables were grown in homestead areas as well as other places for their own consumption and also for income generation. The union had 



Fig. 15: Some pictorial view during data collection of the village study 
some limitations of rural development like lack of capital, limited natural resources and reduction of croplands. Among the crop production problems, high input cost, lack of technical knowledge and availability of quality seeds were considered as the major Area to be taken into consideration to improve the situation. Less than one-third of the farmer was found contacting extension officers (SAAO). So tremendous scope exists to strengthen extension communication by creating awareness and intensive support from the government and non-government agencies (Research, DAE, BADC, NGOs).

\section{RECOMMENDATIONS}

Some specific recommendation and suggestions from the surveyed investigation are pointed below-

- Labor is unavailable in working season and wage is very high; thus, mechanization should be done to save time, money and labor.

- Easy access to agricultural loans and reducing the price of all sorts of agriculture inputs (pesticide, seed, fertilizer, electricity etc.)

- Facilitating electricity operated shallow machine.

- Hybrid/modern varieties' quality seed supplying that are resistant to disease and pest and making them available in markets

- Need-based training conduction. Training should be provided on fruit cultivation at the homestead, soil health improvement and more training should be conducted on vegetable crop production.

- Ensuring fair price of agricultural produces and establishing storage facilities for vegetables and perishables.

- Modernizing the local market system and improving the existing value chain from producer to consumer.

\section{ACKNOWLEDGEMENTS}

Praises are due to almighty Baghban, who enabled me to submit this village study report to the respective module director as per the schedule given by the course administration. I express my deepest gratitude and sincere appreciation to $\mathrm{Md}$. Jamal Uddin, Deputy Director, NATA (National
Agriculture Training Academy), Gazipur and module director, village study for proper guidance and inspiration. I'm also deeply indebted to the course advisor, Dr. Md. Akhtaruzzaman, Director General (In-charge), NATA and course coordinator Dr. Md. Jamal Uddin, Deputy Director (Plant pathology), NATA as well as Dr. Md. Abdul Mazed, Deputy Director (LR), NATA for their constructive suggestions and kind instructions. I am also very much thankful to Md. Shahinul Islam, Senior Assistant Director (Field crop pest) of NATA for his utmost cooperation throughout the study period. My heartiest gratitude to all the NATA staff who were actively involved in this village study course. I wish to convey my gratefulness to all the participants of $\mathrm{N}-27^{\text {th }} \mathrm{FTC}$ for their loving behavior and warmth during this full time of training and study work. I express my deep appreciation and heartfelt thanks to all of the officials of the Department of Agricultural Extension especially, Kbd. Debashis Kumar Das (Upazilla Agriculture Officer) and Sub-Assistant Agriculture Officer Mr. Debasis Das of Kumarkhali, Kushtia for their cordial help to fulfill the village survey. This research study was a part of $\mathrm{N}-27^{\text {th }}$ Foundation Training Course for NARS (National Agricultural Research System) scientists funded by NATP-2 BARC Bangladesh.

\section{REFERENCES}

Ahmed, S., Jahiruddin, M., Sultana, R., Begum, R.A., Biswas, J.C., Rahman, A.S.M.M., Ali, M.M., Islam, K.M.S., Hossain, M.M., Gani, M.N., Hossain, G.M.A. and Satter, M.A. 2018. Fertilizer Recommendation Guide-2018. Bangladesh Agricultural Council (BARC), Farmgate, Dhaka 1215. ISBN: 984-500-029-1, pp. 12, 17.

Alamgir, M.S., Furuya, J., Kobayashi, S., Binte, M.R. and Salam, M.A. 2018. Farmers' Net Income Distribution and Regional Vulnerability to Climate Change: An Empirical Study of Bangladesh. Climate, 6(3): 65.

Azumah, S.B., Donkoh, S.A. and Awuni, J.A. 2018. The perceived effectiveness of agricultural technology transfer methods: Evidence from rice farmers in Northern Ghana. Cogent. Food Agric., 4(1): 1503798.

BARI (Bangladesh Agricultural Research Institute). 2019. Krishi Projukti Hatboi (Handbook on Agro-Technology), $8^{\text {th }}$ edition, Gazipur-1701, Bangladesh, pp. 467-522.

BBS. 2018. Yearbook of Agricultural Statistics of Bangladesh. Statistics Division, Ministry of Planning. Peoples Republic of Bangladesh, pp. 14-29.

BBS. 2019. Yearbook of Agricultural Statistics-2019. $31^{\text {st }}$ Series, Planning Division, Ministry of Planning, Dhaka, Bangladesh, pp. 3-36. 
Chowhan, S. 2020. A review on Bangabandhu and agriculture: Future path for self-sufficiency in food production of Bangladesh. Arch. Agr. Environ. Sci., 5(2): 200-204.

Chowhan, S., Hoque, M.I., Ghosh, S.R., Islam, M. and Akter, M.B. 2019. Effect of Variety and Seedling Number on the Growth and Yield of Boro Rice in Bangladesh. J. Exp. Agr. Int., 41(6): 1-15.

Chowhan, S., Ghosh, S.R., Hoque, M.I., Islam, M. and Nabi, K.M.E. 2020. Yield and Profitability Analysis of Pulse and Oil Seed Based Cropping Patterns against Aman- BoroFallow Cropping Systems in Magura. Agric. Sci. Digest (online first article). doi:10.18805/ag.D-261

Databd.Co. An Overview of Agriculture in Bangladesh. https://databd.co/stories/an-overview-of-agriculture-inbangladesh-4185. Accessed: $28^{\text {th }}$ February 2021.

FAO. 2016. Survey Calendar Expectations from Agriculture Census. http://www.fao.org/fileadmin/templates/rap/ files/meetings /2016/160801_BGD_SurveyCalendar_ Expectations_from_Ag_Census_by_DAE.pdf. Accessed: $28^{\text {th }}$ February 2021.

Ferdous, Z., Datta, A., Anal, A.K., Anwar, M. and Khan, A.S.M.M.R. 2016. Development of home garden model for year round production and consumption for improving resource-poor household food security in Bangladesh. Wageningen J. Life Sci., 78: 103-110.

Hasan, S.S., Ghosh, M.K., Arefin, M.S. and Sultana, S. 2015. Farmers' attitude towards using agro-chemicals in rice production: A case in Laxmipur District of Bangladesh. The Agri., 13(2): 105-112.

Hossain, I., Mondal, M., Islam, M., Aziz, M., Khan, A. and Begum, F. 2015. Four crops based cropping pattern studies for increasing cropping intensity and productivity in Rajshahi region of Bangladesh. Bangladesh Agron. J., 17(2): 55-60.

Islam, A., Shahidullah, S., Mostafizur, A. and Saha, A. 2018. Diversity of Cropping Pattern in Bogra. Bangladesh Rice J., 21(2): 73-90.

Kabir, M.S., Marković, M.R. and Radulović, D. 2019. The Determinants of Income of Rural Women in Bangladesh. Sustainability, 11(20): 5842.

Khan, A. and Akram, M. 2012. Farmers perception of extension methods used by extension personnel for dissemination of new agricultural technologies in khyberpakhtunkhwa: Pakistan. Sarhad J. Agric., 28(3): 511-520.
Khoza, T.M., Senyolo, G.M., Mmbengwa, V.M. and Soundy, P. 2019. Socioeconomic factors influencing smallholder farmers' decision to participate in agro-processing industry in Gauteng province, South Africa. Cogent Soc. Sci., 5(1): 1664193.

Kumar, A., Takeshima, H., Thapa, G., Adhikari, N., Saroj, S., Karkee, M. and Joshi, P.K. 2020. Adoption and diffusion of improved technologies and production practices in agriculture: Insights from a donor-led intervention in Nepal. Land Use Pol., 95: 104621.

Mohiuddin, M., Hossain, M., Rahman, A. and Palash, M. 2009. Socio-economic study of insecticide use on vegetable cultivation at farm level in Chittagong region. J. Bangladesh Agril. Univ., 7(2): 343-350.

Mottaleb, K.A. 2018. Perception and adoption of a new agricultural technology: Evidence from a developing country. Tech. Soc., 55: 126-135.

Tipu, M.N.A. 2018. Women's Participation in Decision-making Process of Local Government in Bangladesh: A Study of Nine Union Parishads. Asian Res. J. Art. Soc. Sci., 5(4): 1-12.

Quddus, A. and Kropp, J.D. 2020. Constraints to Agricultural Production and Marketing in the Lagging Regions of Bangladesh. Sustainability, 12(10): 3956.

Roy, P., Haque, S., Jannat, A., Ali, M. and Khan, M. 2017. Contribution of women to household income and decision making in some selected areas of Mymensingh in Bangladesh. Prog. Agr., 28(2): 120-129.

Salam, S., Bauer, S. and Palash, M.S. 2019. Impact of income diversification on rural livelihood in some selected areas of Bangladesh. J. Bangladesh Agril. Univ., 17(1): 73-79.

Statistix. 2021. Data analysis software for researchers (Version 10.0). Analytical Software, 2105 Miller Landing Rd, Tallahassee Florida 32312, USA, 2021. https://www. statistix.com/. Accessed: $28^{\text {th }}$ February 2021.

World Population Review. 2019. Bangladesh Population, http://worldpopulationreview.com /countries/ bangladeshpopulation/. Accessed: $28^{\text {th }}$ February 2021.

Wossen, T., Alene, A., Abdoulaye, T., Feleke, S. and Manyong, V. 2019. Agricultural technology adoption and household welfare: Measurement and evidence. Food Pol., 87: 101742. 
